\title{
Intraspecific, Interspecific, and Interseries Cross-compatibility in Lilac
}

\author{
Jason D. Lattier ${ }^{1}$ and Ryan N. Contreras ${ }^{2}$ \\ Department of Horticulture, 4017 Agriculture and Life Sciences Building, Oregon State University, \\ Corvallis, OR 97331-7304
}

\begin{abstract}
AdDitional Index words. Syringa, Pubescentes, Villosae, in vitro germination, controlled crosses, wide hybridization
Abstract. Lilacs (Syringa sp.) are a group of ornamental trees and shrubs in the Oleaceae composed of 22-30 species from two centers of diversity: the highlands of East Asia and the Balkan-Carpathian region of Europe. There are six series within the genus Syringa: Pubescentes, Villosae, Ligustrae, Ligustrina, Pinnatifoliae, and Syringa. Intraspecific and interspecific hybridization are proven methods for cultivar development. However, reports of interseries hybridization are rare and limited to crosses among taxa in series Syringa and Pinnatifoliae. Although hundreds of lilac cultivars have been introduced, fertility and cross-compatibility have yet to be formally investigated. Over 3 years, a cross-compatibility study was performed using cultivars and species of shrub-form lilacs in series $\mathbf{S y r i n g a}$, Pubescentes, and Villosae. A total of 114 combinations were performed at an average of $243 \pm 27$ flowers pollinated per combination. For each combination, we recorded the number of inflorescences and flowers pollinated as well as number of capsules, seed, seedlings germinated, and albino seedlings. Fruit and seed were produced from interseries crosses, but no seedlings were recovered. A total of 2177 viable seedlings were recovered from interspecific and intraspecific combinations in series Syringa, Pubescentes, and Villosae. Albino progeny were produced only from crosses with Syringa pubescens ssp. patula 'Miss Kim'. In vitro germination was attempted on 161 seed from interseries crosses, resulting in three germinations from $S$. pubescens Bloomerang ${ }^{\circledR}$ x Syringa vulgaris 'Ludwig Spaeth'. None survived, yet cotyledons produced callus for future efforts to induce embryogenic shoots. This study is a comprehensive investigation of lilac hybridization, and the knowledge gained will aid future efforts in lilac cultivar development.
\end{abstract}

Syringa is a diverse genus in the olive family (Oleaceae) representing 22-30 species from two centers of diversity: the highlands of East Asia and the Balkan-Carpathian region of Europe (Kochieva et al., 2004). Most lilacs are native to Asia, whereas $S$. vulgaris and $S$. josikaea are native to southeastern Europe (Kim and Jansen, 1998). Hundreds of cultivars have been produced and are ubiquitous in temperate gardens around the world. Historically, the most popular cultivars originated $S$. vulgaris, primarily grown for its fleeting spring blooms of purple, pink, blue, or white fragrant flowers. Previous phylogenies have divided lilacs into subgenera and four series (Rehder, 1945) which were later confirmed as monophyletic groups using plastid DNA (Kim and Jansen, 1998). The current phylogeny by Li et al. (2012) based on nuclear and plastid DNA sequences recognizes six series: Pubescentes, Villosae, Ligustrina, Ligustrae, Pinnatifoliae, and Syringa (Vulagares).

Each series has distinguishing morphological features. Series Syringa is unique by having simple, glabrous leaves while series Pubescentes has pubescent leaves (Li et al., 2012). Series Villosae is distinct by having inflorescences develop from a single terminal bud with lateral, vegetative buds (Kim and Jansen, 1998). Ligustrina differs by its privet-like flowers (short, white corolla tubes with exerted anthers) and growth

Received for publication 3 May 2017. Accepted for publication 5 June 2017. This research was funded in part by the Oregon Department of Agriculture Nursery Research Grant Program.

We wish to thank Mara Friddle, Kim Shearer, Aleen Haddad, and the entire staff of the Ornamental Plant Breeding Lab at Oregon State University for technical support.

${ }^{1}$ Graduate Research Assistant.

${ }^{2}$ Corresponding author. E-mail: ryan.contreras@oregonstate.edu. habit as a tree (Kim and Jansen, 1998). Pinnatifoliae is distinguished by having pinnately compound leaves ( $\mathrm{Li}$ et al., 2012). Ligustrae contains several privets (Ligustrum sp.) nested within the lilacs (Li et al., 2012).

Lilacs are of major economic importance to the United States nursery industry. In 2014, nationwide sales topped 1.8 million generating more than $\$ 20$ million in total revenues (U.S. Department of Agriculture, 2016). Intraspecific and interspecific hybridization have proven to be valuable methods for the development of lilac cultivars. Interspecific hybridization has been particularly useful at producing cultivars with improved flowering and new foliar phenotypes (Table 1). Lilac breeding was scarce before the 1800 s, a time when selections focused on improved form, flower color, or spring flush in chance seedlings (Fiala and Vrugtman, 2008). Early advancements in breeding produced vigorous interspecific hybrids including $S$. Xhyacinthiflora from crosses between S. oblata and S. vulgaris by the Lemoine nursery (Lemoine, 1878; Sax, 1930). This nursery was responsible for 214 cultivars and caused a spike in popularity of lilacs in the 1900s (Fiala and Vrugtman, 2008). Many breeders emerged to produce cultivars with a wide range of ornamental traits. Descanso Gardens in southern California and the United States National Arboretum focused on improving $S$. xhyacinthiflora hybrids for southern climates by incorporating low chilling requirements and powdery mildew resistance (Fiala and Vrugtman, 2008).

Cultivar improvement in series Villosae began its ascendancy with complex interspecific hybridization involving S. reflexa by Isabella Preston in Ottawa, ON, Canada (Fiala and Vrugtman, 2008). A total of 47 cultivars were introduced 
Table 1. Interspecific hybrids in lilac and their parent species (Fiala and Vrugtman, 2008).

\begin{tabular}{lllll}
\hline Interspecific hybrid & \multicolumn{1}{c}{ Parent 1} & \multicolumn{1}{c}{ Series } & \multicolumn{1}{c}{ Parent 2 } & Series \\
\hline Syringa $\times$ chinensis & S. protolaciniata & Syringa & S. vulgaris & Syringa \\
Syringa $\times$ diversifolia & S. pinnatifolia & Pinnatifoliae & S. oblata ssp. oblata & Syringa \\
Syringa $\times$ henryi & S. josikaea & Villosae & S. villosa & Villosae \\
Syringa $\times$ hyacinthiflora & S. oblata & Syringa & S. vulgaris & Syringa \\
Syringa $\times$ josiflexa & S. josikaea & Villosae & S. reflexa & Villosae \\
Syringa $\times$ laciniata & Unknown & Unknown & Unknown & Unknown \\
Syringa $\times$ nanceiana & Syringa $\times$ henryi & Villosae & Syringa sweginzowii Villosae \\
Syringa $\times$ persica & Unknown & Unknown & Unknown & Unknown \\
Syringa $\times$ prestoniae & S. villosa & Villosae & S. komarowii & Villosae \\
Syringa $\times$ swegiflexa & S. komarowii & Villosae & S. sweginzowii & Villosae \\
\hline Intid
\end{tabular}

${ }^{\mathrm{z}}$ Interseries hybrid.

from the interspecific hybrids $S$. ×prestoniae and $S$. ×josiflexa, which were created by crossing several species in series Villosae (S. villosa, S. reflexa, and $S$. josikaea) (Table 1) (Fiala and Vrugtman, 2008). One of Preston's contemporaries, Frank Skinner, produced similar interspecific hybrids in Villosae, several of which are still available in the trade (Fiala and Vrugtman, 2008).

Ornamental traits in series Pubescentes have been noted since the early 1900s when director of the Arnold Arboretum, Charles Sargent, noted in a wild-collected specimen of $S$. pubescens, "...if it keeps up its habit of flowering a second time in autumn, it will at least be interesting even if other lilacs are more beautiful." Remontancy (or reblooming) as noted by Sargent would become one of the most pursued traits by modern lilac breeders (Fiala and Vrugtman, 2008). Early introductions in series Pubescentes exhibited improved form and flowers in addition to cold hardiness from wild-collected $S$. pubescens ssp. patula from E.H. Wilson's Diamond Mountain expedition in Korea (Fiala and Vrugtman, 2008). Most new cultivars in series Pubescentes are prolific flowering, compact, and disease resistant with several cultivars exhibiting summer remontancy.

In contrast to the success of interspecific hybridization, interseries hybridization has proven more difficult with the only successful hybrids from crosses between taxa in series Syringa and series Pinnatifoliae (Pringle, 1981). Interseries hybridization has been a goal of breeders for nearly a century, as illustrated by early reports: "...combinations of the early blooming Syringa vulgaris varieties with the late Villosae species would undoubtedly be of value if they could be made..." (Sax, 1930). Previous attempts to create interseries hybrids resulted in abortive fruit with no germination of recovered seed (Pringle, 1981).

Abortive seed in lilacs has been explored in previous research. Anatomical studies on $S$. villosa, a species with high rates of seed abortion, found that after cross-pollination, embryos developed normally through the globular, heart, torpedo, and cotyledon stages before embryo and endosperm degradation (Chen et al., 2012). Few embryo rescue studies have been attempted in lilacs. However, Zhou et al. (2003) successfully cultured immature embryos on Monnier's medium (Monnier, 1990) supplemented with 1-naphthaleneacetic acid, 6-benzylaminopurine (BAP), glutamine, and a high concentration of sucrose, indicating that tissue culture may be a platform for recovering hybrid lilacs. Even if in vitro germination fails, callus developed from the hybrid tissue may provide another source for producing interseries hybrids. Lilac somatic embryogenesis protocols using cotyledons have recently been developed for $S$. reticulata var. mandshurica (Liu et al., 2013).

Although hundreds of improved lilac cultivars have been introduced, fertility and cross-compatibility among cultivars, species, and series have yet to be investigated in a formal study. The objectives of this study were to 1) investigate cross-compatibility of elite cultivars in intraspecific, interspecific, and interseries combinations and 2) investigate the potential for interseries hybridization and in vitro embryo rescue of abortive embryos.

\section{Materials and Methods}

Parent material. Parents were collected from nurseries, gardens, and arboreta from 2009 to 2014 (Table 2) that provided cultivar and trademark names. Full scientific names, cultivars, and trademarks are reported (Table 2), but for simplicity only market names (cultivar or trademark) are used hereafter. Taxonomic designations reflect current phylogenies and revisions, including the use of subspecies designations in Pubescentes (Chen et al., 2009). Representative species and cultivars were obtained from series Syringa, Pubescentes, and Villosae focusing on elite cultivars improved for ornamental traits including flower colors and forms, leaf pigments, and novel growth habits including dwarf habits.

Flower colors included white, pink, blue, and purple, with one taxon, S. vulgaris 'Sensation', having picotee flowers in which the petal edges lack pigment. Flower forms included single and double flowers, with some exhibiting hose-in-hose flowers. Double flowers in lilac often represent a case of neoheterotrophy where additional floral whorls lead to supernumerary petals (Dadpour et al., 2011). Double flowers can also arise from mutations leading to petaloid sepals (Fiala, 1988). Both cases leave reproductive whorls intact and allow for double-flowered cultivars to be used in reciprocal crosses. Foliar pigments were rare across the breeding population, occurring in a spring flush of yellow or purple leaves (Fig. 1). Syringa emodii in series Villosae was the only taxon that produced a yellow flush of leaves (Fig. 1A). Purple color of spring foliage was limited to purpleflowered taxa in series Syringa, but was most pronounced in S. ×hyacinthiflora 'Old Glory' (Fig. 1B). Novel variations in form were limited to two dwarf taxa in series Syringa, S. vulgaris 'Tiny Dancer' and S. vulgaris 'Prairie Petite'.

Crosses. During the spring and summer of 2013, 2014, and 2015 , a total of 27,645 cross-pollinations were made. Of these, 114 crosses were performed with an average of $243 \pm 27$ flowers pollinated per cross. For each series, three types of crosses were attempted: intraspecific, interspecific, and interseries (Tables 3-5, respectively). Within each series, crosses made with at least one interspecific parent (e.g., $S$. $\times$ hyacinthiflora $\mathrm{x} S$. oblata) were classified as interspecific. Most cultivars in Villosae were interspecific hybrids; each replicate of an unimproved species was collected from a single source. For example, we received $S$. emodii from a single Index Seminum source. Consequently, crosses with Villosae focused on interseries and interspecific combinations because intraspecific crosses would likely involve significant inbreeding. 
Table 2. Source material for lilac breeding population.

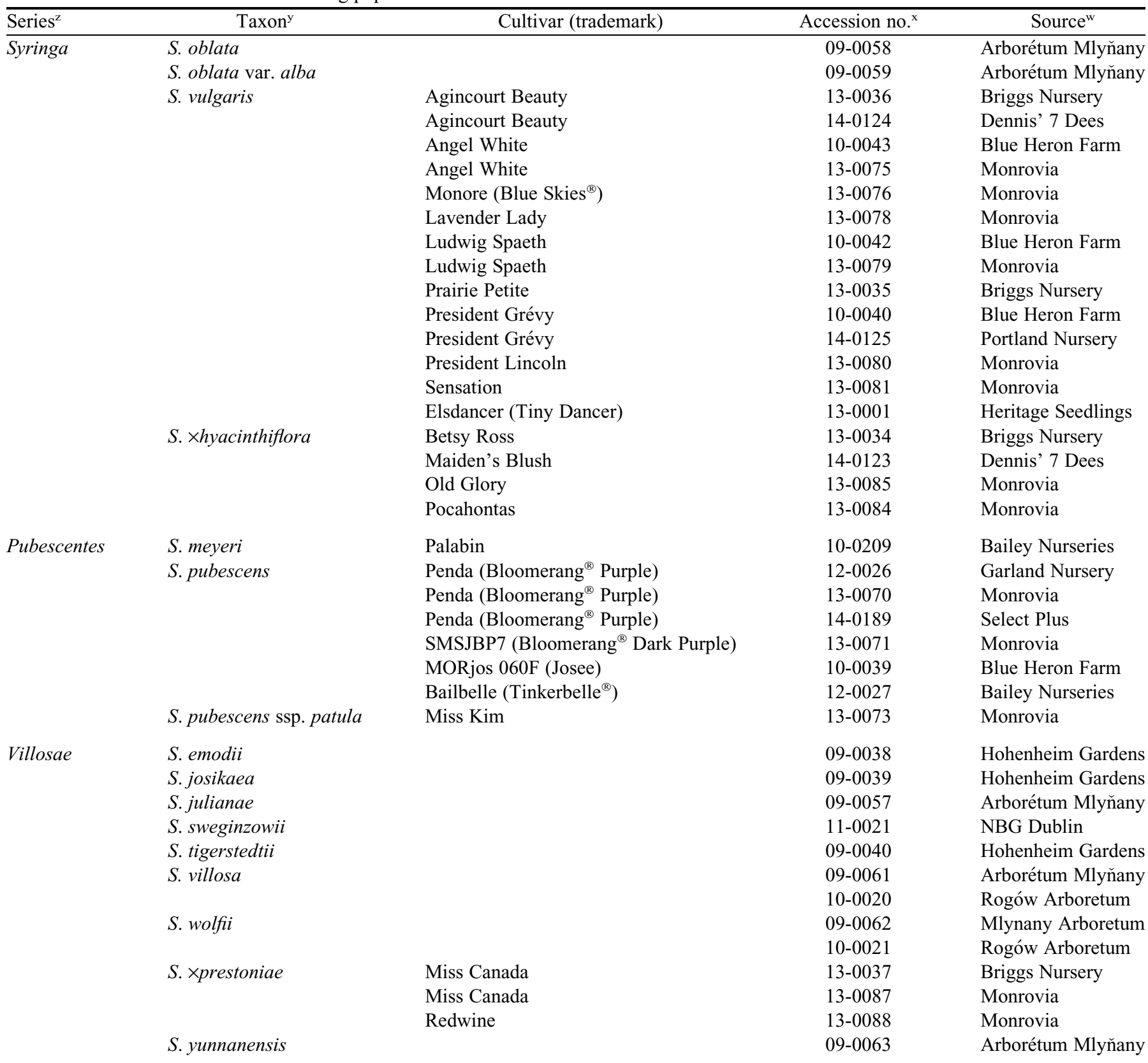

${ }^{\bar{z}}$ Series designation based on phylogeny by Li et al. (2012).

${ }^{\mathrm{y}}$ Individual taxon in Syringa based on current phylogeny (Li et al., 2012) and revisions (Chen et al., 2009).

${ }^{\mathrm{x}}$ Accession number in research collection at Oregon State University, Corvallis, OR. Duplicate samples were clones and phenotypically identical.

${ }^{\mathrm{w}}$ Container plants, seed, and leaf samples collected from the following sources: Arborétum Mlyñany (Slepcany, Slovakia), Bailey Nurseries (Yamhill, OR), Blue Heron Farm (Corvallis, OR), Briggs Nursery (Elma, WA), Carlton Plants (Dayton, OR), Dennis' 7 Dees Landscaping \& Garden Centers (Portland, OR), Garland Nursery (Corvallis, OR), Heritage Seedlings \& Liners (Salem, OR), Hohenheim Gardens (Stuttgart, Germany), Mason Hollow Nursery (Mason, NH), Monrovia (Dayton, OR), National Botanic Gardens [NBG Dublin (Glasnevin, Ireland)], Portland Nursery (Portland, OR), Rogów Arboretum (Rogów, Poland), Select Plus International Lilac Nursery (Mascouche, QC, Canada).

Each year, fresh pollen was collected and stored in small petri dishes over desiccant (Drierite; W.A. Hammond Drierite, Xenia, $\mathrm{OH})$ in a refrigerator at $4{ }^{\circ} \mathrm{C}$. Before pollination, open flowers were removed on all inflorescences and saved in glassine bags for pollen collection and reciprocal crosses. Individual flowers were emasculated before anthesis and pollinations were made in a glasshouse free of pollinators with day/night temperatures of $25 / 20{ }^{\circ} \mathrm{C}$ and a $16-\mathrm{h}$ photoperiod. Each flower was pollinated using a brush two to three times postemasculation over consecutive days. Brushes were sterilized before and between pollinations using 70\% ethanol. Incidences of self-pollination were tested by covering two inflorescences per plant with organza bags and shaking occasionally. Self-pollination can also occur if pollen is released during emasculation. Self-pollination during emasculation was tested by emasculating multiple inflorescences (200+ flowers) on two fertile parents ( $S$. vulgaris 'Angel White' and $S$. vulgaris 'Ludwig Spaeth') and covering the inflorescences with organza 

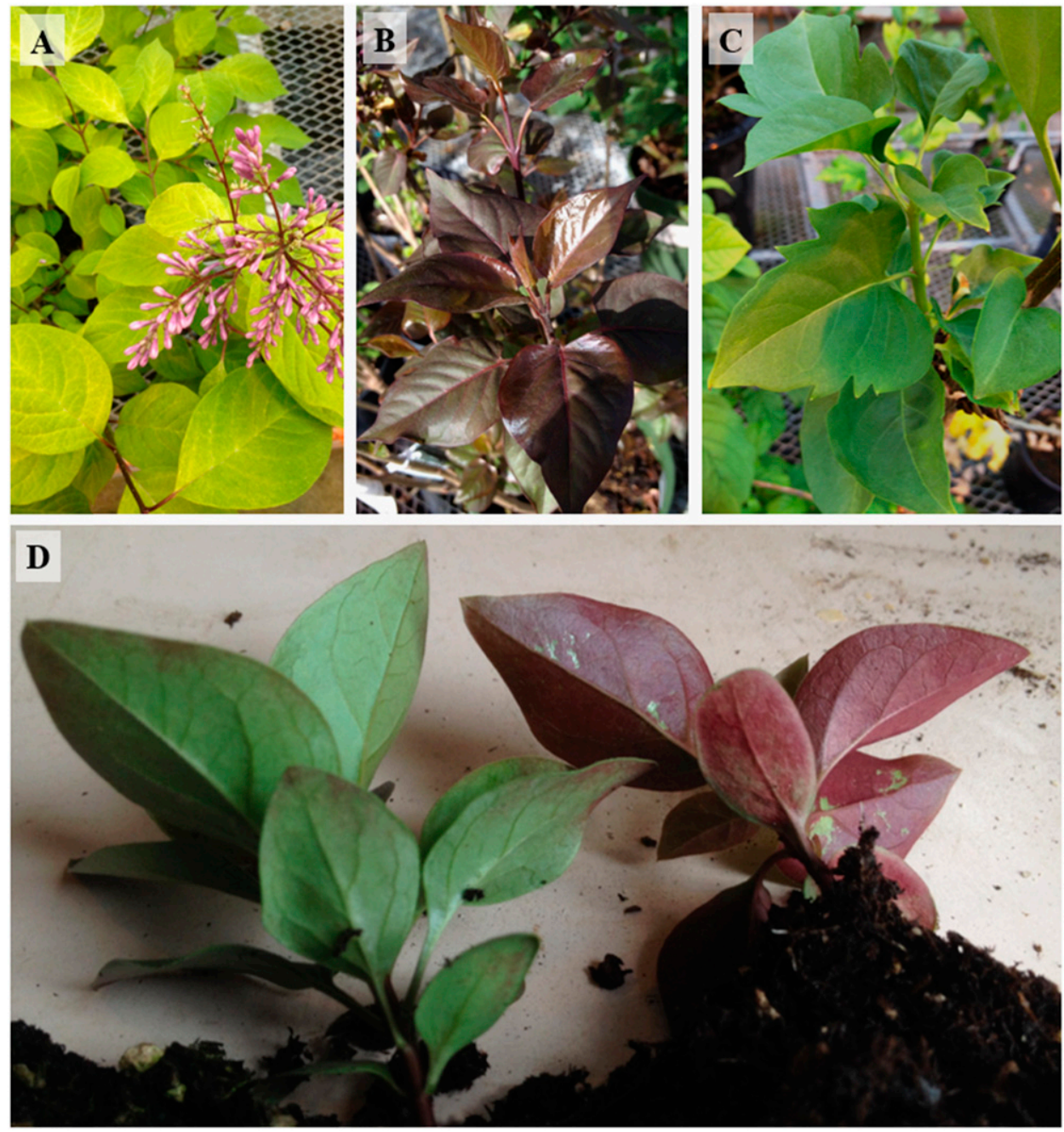

Fig. 1. Spring leaf color phenotypes in lilac breeding population: (A) yellow-green leaves of Syringa emodii, (B) purple leaves of Syringa $\times$ hyacinthiflora 'Old Glory', (C) hybrid seedling (H2013-150-001) from the cross Syringa vulgaris 'President Grévy' $\mathrm{x}$ Syringa vulgaris 'Sensation', and (D) hybrid seedlings from the cross Syringa vulgaris 'Ludwig Spaeth' $\mathrm{x}$ Syringa vulgaris 'Angel White' segregating for abaxial leaf pigment.

bags. Developing fruit were counted throughout the summer and dry fruit were collected before dehiscence during fall. Data were collected on number of pollinated inflorescences, pollinated flowers, and developing fruit. During fall, seed were cleaned and counted before cold stratification during winter.

SEed Germination. Seed were placed in plastic bags filled with moist stratification media consisting of half perlite (Supreme Perlite Co., Portland, OR) and half growing medium (Metro-Mix; Sun Gro Horticulture, Agawam, MA). Seed were cold-stratified for 10 weeks at $4{ }^{\circ} \mathrm{C}$. After stratification, seed were sown in 1.3-L containers filled with the growing medium and treated once with copper hydroxide (Kocide 2000; DuPont, Wilmington, DE) at $0.3 \mathrm{mg} \cdot \mathrm{L}^{-1}$. For each cross, no more than 30 seed were sown per pot. Seedlings were germinated in a glasshouse under the conditions described previously. Data collected over winter included number of germinated seed, albino seedlings, and viable green seedlings.

IN VITRO GERMINATION. Capsules progressed from pollination to dehiscence over a 20- to 30-week period in the glasshouse. In 2013 , observations of early fruit abortion at 6 weeks postpollination in the interseries cross $S$. oblata x $S$. pubescens Bloomerang ${ }^{\circledR}$ Purple prompted an in vitro germination trial on a subset of developing fruit (Table 6). In subsequent years, fruit were allowed to dehisce early, and seed were sown according to the methods previously mentioned. For in vitro germination, interseries hybrid fruit from five crosses (Table 6) were collected 7 weeks after pollination. Green fruit were collected and immediately surface-sterilized by rinsing in a $70 \%$ ethanol solution for $30 \mathrm{~s}$ followed by a soak in a $6.15 \%(\mathrm{v} / \mathrm{v})$ sodium hyporchlorite solution with several drops of surfactant (Tween 20; Acros Organics, Fair Lawn, NJ). Fruit were triple rinsed and temporarily stored in filter-sterilized, autoclaved water. Fruit were dissected in a sterile, laminar flow hood using a dissecting microscope. Green seed were removed from capsules into sterile petri dishes containing an aqueous solution of L-ascorbic acid at 25 $\mathrm{mg} \cdot \mathrm{L}^{-1}$ to reduce oxidation. Embryo extraction at this early stage proved too damaging to young tissues. Therefore, intact dissected seed were cultured on an embryo rescue medium.

Dissected seed were cultured on Monnier's medium according to the lilac embryo rescue protocol of Zhou et al. (2003) and incubated under standard culture conditions $\left(24 \pm 2{ }^{\circ} \mathrm{C}\right.$ and a $16-\mathrm{h}$ photoperiod of $60 \mu \mathrm{mol} \cdot \mathrm{m}^{-2} \cdot \mathrm{s}^{-1}$ provided by cool-white fluorescent lamps). Seed were incubated on $10 \mathrm{~mL}$ of the embryo rescue medium in $150-\mathrm{mm}$ culture tubes. Tubes were capped and sealed with paraffin film (parafilm; American National Can Co., Menasha, WI). A total of 161 seed were placed on the germination medium, representing five interseries crosses. Culture tubes were completely randomized and maintained in racks of 40 tubes. Germination was observed and recorded over 3 months. On germination, seedlings and callus were transferred to the shoot regeneration medium composed of Murashige and Skoog basal salts and vitamins, $5 \mu \mathrm{M}$ BAP, $0.5 \mu \mathrm{M}$ indole-3-butyric acid (IBA), 100 $\mathrm{mg} \cdot \mathrm{L}^{-1}$ myo-inositol, $100 \mathrm{mg} \cdot \mathrm{L}^{-1}$ 2-(N-morpholino) ethanesulfonic acid (MES monohydrate), and $30 \mathrm{~g} \cdot \mathrm{L}^{-1}$ sucrose. The solution containing basal salts, vitamins, and hormones (Phytotechnology Laboratories, Shawnee Mission, KS) was adjusted to $\mathrm{pH} 5.8$ and solidified with $7.5 \mathrm{~g} \cdot \mathrm{L}^{-1}$ agar (SigmaAldrich, St. Louis, MO).

\section{Results and Discussion}

A total of 3668 capsules were collected which produced 4890 seed and 2177 viable (nonalbino) hybrid seedlings. No fruit or seed resulted from emasculated/unpollinated flowers from the first self-pollination test. Six taxa produced seed from 
Table 3. Intraspecific cross-compatibility within series Pubescentes and Syringa in lilac.

\begin{tabular}{|c|c|c|c|c|c|c|}
\hline Series $^{z}$ & Female parent & Male parent & $\begin{array}{c}\text { Pollinations } \\
(\text { no. })^{\mathrm{y}}\end{array}$ & $\begin{array}{c}\text { Capsules } \\
(\text { no. })^{\mathrm{x}}\end{array}$ & $\begin{array}{c}\text { Seed } \\
(\text { no. })^{\mathrm{w}}\end{array}$ & $\begin{array}{c}\text { Germinated } \\
(\text { no. })^{\mathrm{v}}\end{array}$ \\
\hline \multirow[t]{9}{*}{ Pubescentes } & S. pubescens Bloomerang ${ }^{\circledR}$ Purple & S. pubescens Josee & 141 & 28 & 41 & 20 \\
\hline & & S. pubescens 'Miss Kim' & 175 & 1 & 1 & 0 \\
\hline & S. pubescens Josee & S. pubescens Bloomerang ${ }^{\circledR}$ Purple & 246 & 67 & 158 & 131 \\
\hline & & S. pubescens 'Miss Kim' & 137 & 4 & 5 & 0 \\
\hline & & S. pubescens Tinkerbelle ${ }^{\circledR}$ & 145 & 31 & 42 & 28 \\
\hline & & S. pubescens Josee & 210 & 0 & 0 & 0 \\
\hline & S. pubescens Tinkerbelle ${ }^{\circledR}$ & S. pubescens Bloomerang ${ }^{\circledR}$ Purple & 290 & 20 & 15 & 10 \\
\hline & & S. pubescens Josee & 199 & 0 & 0 & 0 \\
\hline & & S. pubescens 'Miss Kim' & 124 & 0 & 0 & 0 \\
\hline \multirow[t]{12}{*}{ Syringa } & S. vulgaris Tiny Dancer & S. vulgaris 'Angel White' & 270 & 3 & 0 & 0 \\
\hline & & S. vulgaris 'President Grévy' & 238 & 68 & 72 & 12 \\
\hline & S. vulgaris 'Lavender Lady' & S. vulgaris Tiny Dancer & 176 & 75 & 93 & 47 \\
\hline & S. vulgaris 'Ludwig Spaeth' & S. vulgaris 'Angel White' & 273 & 182 & 422 & 186 \\
\hline & S. vulgaris 'Prairie Petite' & S. vulgaris 'Sensation' & 74 & 33 & 0 & 0 \\
\hline & S. vulgaris 'President Grévy' & S. vulgaris Tiny Dancer & 304 & 3 & 2 & 0 \\
\hline & & S. vulgaris 'Angel White' & 182 & 4 & 3 & 0 \\
\hline & & S. vulgaris 'President Lincoln' & 81 & 0 & 0 & 0 \\
\hline & & S. vulgaris 'Sensation' & 240 & 100 & 107 & 1 \\
\hline & S. vulgaris 'President Lincoln' & S. vulgaris 'Angel White' & 135 & 27 & 23 & 12 \\
\hline & & S. vulgaris 'President Grévy' & 126 & 0 & 0 & 0 \\
\hline & S. vulgaris 'Sensation' & S. vulgaris Tiny Dancer & 95 & 12 & 14 & 20 \\
\hline
\end{tabular}

${ }^{\mathrm{Z}}$ Intraspecific crosses within two series of lilac: Pubescentes and Syringa (Li et al., 2012).

${ }^{\mathrm{y}}$ Number of emasculated flowers pollinated.

${ }^{\mathrm{x}}$ Number of capsules formed from controlled crosses.

${ }^{\mathrm{w}}$ Number of seed produced from controlled crosses.

${ }^{\mathrm{v}}$ Number of seed germinated.

${ }^{\mathrm{u}}$ All nonviable albino seedlings.

the nonemasculated, self-pollination tests, but only two taxa produced viable seedlings. Syringa pubescens Tinkerbelle $^{\circledR}$ selfpollinations yielded 36 seed and 20 viable seedlings. Syringa meyeri 'Palabin' self-pollinations yielded one seed and one viable seedling. The following taxa self-pollinations yielded three or fewer seed and no viable seedlings: $S$. $\times$ hyacinthiflora 'Old Glory', S. vulgaris Blue Skies ${ }^{\circledR}$, S. vulgaris 'Sensation', and S. vulgaris Tiny Dancer. Because each self-pollination test was performed on more than 200 flowers per taxon, incidences of self-pollinations were determined to be negligible during controlled crosses.

Viable seedlings across all taxa exhibited a quiescent phase of vegetative growth during their first year. During this period, seedlings produced few sets of leaves while they developed an expansive root system. In following years, these seedlings exhibited large flushes of vegetative growth. Few phenotypic observations could be made on young seedlings, except for variation in form and leaf pigments. All hybrid seedlings exhibited entire margins except for a single seedling from the cross between the double-flowered $S$. vulgaris 'President Grévy' and picotee-flowered S. vulgaris 'Sensation' (Fig. 1C). This hybrid (H2013-150-001) had leaves with irregular sinuses in its second and third years of growth. In series
Syringa, seedlings of parents with lavender or dark purple flowers had a range of abaxial foliar pigment levels. Seedlings with the darkest pigment were from crosses with the purpleleaved S. ×hyacinthiflora 'Old Glory' (Fig. 1B). The widest range of color segregation was observed in S. vulgaris 'Ludwig Spaeth' x S. vulgaris 'Angel White' where leaf color ranged from green to dark purple (Fig. 1D). In series Pubescentes, one parent, S. pubescens ssp. patula 'Miss Kim', produced only nonviable, albino progeny which failed to survive germination.

INTRASPECIFIC HYBRIDIZATION. Within series Pubescentes, a total of 2180 pollinations resulted in an average of $17.18 \pm$ 11.75 viable seedlings per cross. However, only four crosses yielded viable seedlings of the 11 attempted. The most prolific cross was between two remontant taxa, $S$. pubescens Josee $\times$ S. pubescens Bloomerang ${ }^{\circledR}$ Purple, which produced 131 viable seedlings at 0.53 seedlings per pollinated flower (Table 3 ). The reciprocal cross produced 20 viable seedlings at 0.14 seedlings per pollinated flower (Table 3). Syringa pubescens Josee was also an effective seed parent in crosses with $S$. pubescens Tinkerbelle ${ }^{\circledR}$, yielding 28 viable seedlings at 0.19 seedlings per pollinated flower (Table 3). The fewest viable seedlings were produced from $S$. pubescens Tinkerbelle ${ }^{\circledR}$ x $S$. pubescens 
Table 4. Interspecific cross-compatibility within series Pubescentes, Syringa, and Villosae in lilac.

\begin{tabular}{|c|c|c|c|c|c|c|}
\hline Series $^{\mathrm{z}}$ & Female parent & Male parent & $\begin{array}{l}\text { Pollinations } \\
\text { (no. })^{\mathrm{y}}\end{array}$ & $\begin{array}{l}\text { Capsules } \\
\text { (no.) })^{\mathrm{x}}\end{array}$ & $\begin{array}{l}\text { Seed } \\
\text { (no.) }{ }^{\mathrm{w}}\end{array}$ & $\begin{array}{c}\text { Germinated } \\
\text { (no. })^{\mathrm{v}}\end{array}$ \\
\hline \multirow[t]{5}{*}{ Pubescentes } & S. meyeri 'Palabin' & S. pubescens Bloomerang ${ }^{\circledR}$ Purple & 239 & 144 & 398 & 278 \\
\hline & & S. pubescens Josee & 706 & 47 & 47 & 19 \\
\hline & & S. pubescens Tinkerbelle ${ }^{\circledR}$ & 206 & 83 & 155 & 134 \\
\hline & S. pubescens Josee & S. meyeri 'Palabin' & 122 & 38 & 82 & 63 \\
\hline & S. pubescens 'Miss Kim' & S. meyeri 'Palabin' & 601 & 417 & 900 & $149^{u}$ \\
\hline \multirow[t]{16}{*}{ Syringa } & S. oblata & S. vulgaris Tiny Dancer & 92 & 13 & 14 & 10 \\
\hline & & S. vulgaris 'Lavender Lady' & 162 & 0 & 0 & 0 \\
\hline & S. oblata var. alba & S. vulgaris Tiny Dancer & 208 & 53 & 75 & 47 \\
\hline & & S. vulgaris 'President Lincoln' & 226 & 0 & 0 & 0 \\
\hline & S. vulgaris Tiny Dancer & S. oblata & 175 & 17 & 10 & 8 \\
\hline & S. vulgaris Blue Skies ${ }^{\circledR}$ & S. oblata var. alba & 103 & 5 & 5 & 4 \\
\hline & & S. $\times$ hyacinthiflora 'Betsy Ross' & 135 & 103 & 214 & 191 \\
\hline & S. vulgaris 'Lavender Lady' & S. oblata & 131 & 48 & 67 & 49 \\
\hline & & S. oblata var. alba & 155 & 6 & 2 & 0 \\
\hline & S. vulgaris 'Prairie Petite' & S. $\times$ hyacinthiflora 'Old Glory' & 20 & 0 & 0 & 0 \\
\hline & S. vulgaris 'President Grévy' & S. $\times$ hyacinthiflora 'Old Glory' & 176 & 59 & 76 & 0 \\
\hline & S. vulgaris 'Sensation' & S. ×hyacinthiflora 'Old Glory' & 173 & 73 & 0 & 0 \\
\hline & S. $\times$ hyacinthiflora 'Betsy Ross' & S. oblata & 79 & 2 & 2 & 1 \\
\hline & & S. oblata var. alba & 112 & 8 & 8 & 5 \\
\hline & S. $\times$ hyacinthiflora 'Maiden's Blush' & S. oblata & 164 & 11 & 15 & 13 \\
\hline & S. $\times$ hyacinthiflora 'Old Glory' & S. oblata & 234 & 70 & 154 & 125 \\
\hline & S. julianae & S. ×prestoniae 'Miss Canada' & 255 & 69 & 122 & 100 \\
\hline & S. villosa & S. ×prestoniae 'Miss Canada' & 181 & 0 & 0 & 0 \\
\hline & & S. emodii & 169 & 0 & 0 & 0 \\
\hline & & S. wolfii & 179 & 0 & 0 & 0 \\
\hline & S. wolfii & S. ×prestoniae 'Miss Canada' & 175 & 0 & 0 & 0 \\
\hline & & S. emodii & 215 & 31 & 25 & 24 \\
\hline & & S. villosa & 178 & 11 & 14 & 6 \\
\hline & S. yunnanensis & S. julianae & 177 & 0 & 0 & 0 \\
\hline & & S. ×prestoniae 'Miss Canada' & 209 & 0 & 0 & 0 \\
\hline & S. ×prestoniae 'Miss Canada' & S. wolfii & 254 & 0 & 0 & 0 \\
\hline
\end{tabular}

${ }^{\mathrm{z}}$ Interspecific crosses within three series of lilac: Pubescentes, Syringa, and Villosae (Li et al., 2012).

${ }^{\mathrm{y}}$ Number of emasculated flowers pollinated.

${ }^{\mathrm{x}}$ Number of capsules formed from controlled crosses.

${ }^{\mathrm{w}}$ Number of seed produced from controlled crosses.

${ }^{\mathrm{v}}$ Number of seed germinated.

${ }^{\mathrm{u}}$ Nonviable albino seedlings produced.

Bloomerang ${ }^{\circledR}$ with only 10 viable seedlings produced at 0.03 seedlings per pollinated flower (Table 3 ).

Within series Syringa, a total of 3209 pollinations resulted in an average of $24.24 \pm 11.28$ viable seedlings per cross. Of the 17 crosses attempted, eight yielded viable seedlings. The most prolific was $S$. vulgaris 'Ludwig Spaeth' x S. vulgaris 'Angel
White' producing 186 seedlings at 0.68 seedlings per pollinated flower (Table 3). Of the dwarfs, $S$. vulgaris 'Prairie Petite' was the smallest and slowest growing, producing few inflorescences each year. One cross performed with $S$. vulgaris 'Prairie Petite' used 74 pollinations with $S$. vulgaris 'Sensation' and yielded 33 capsules but no seed (Table 3). The dwarf S. vulgaris Tiny Dancer was 
Table 5. Interseries cross-compatibility among series Pubescentes, Syringa, and Villosae in lilac.

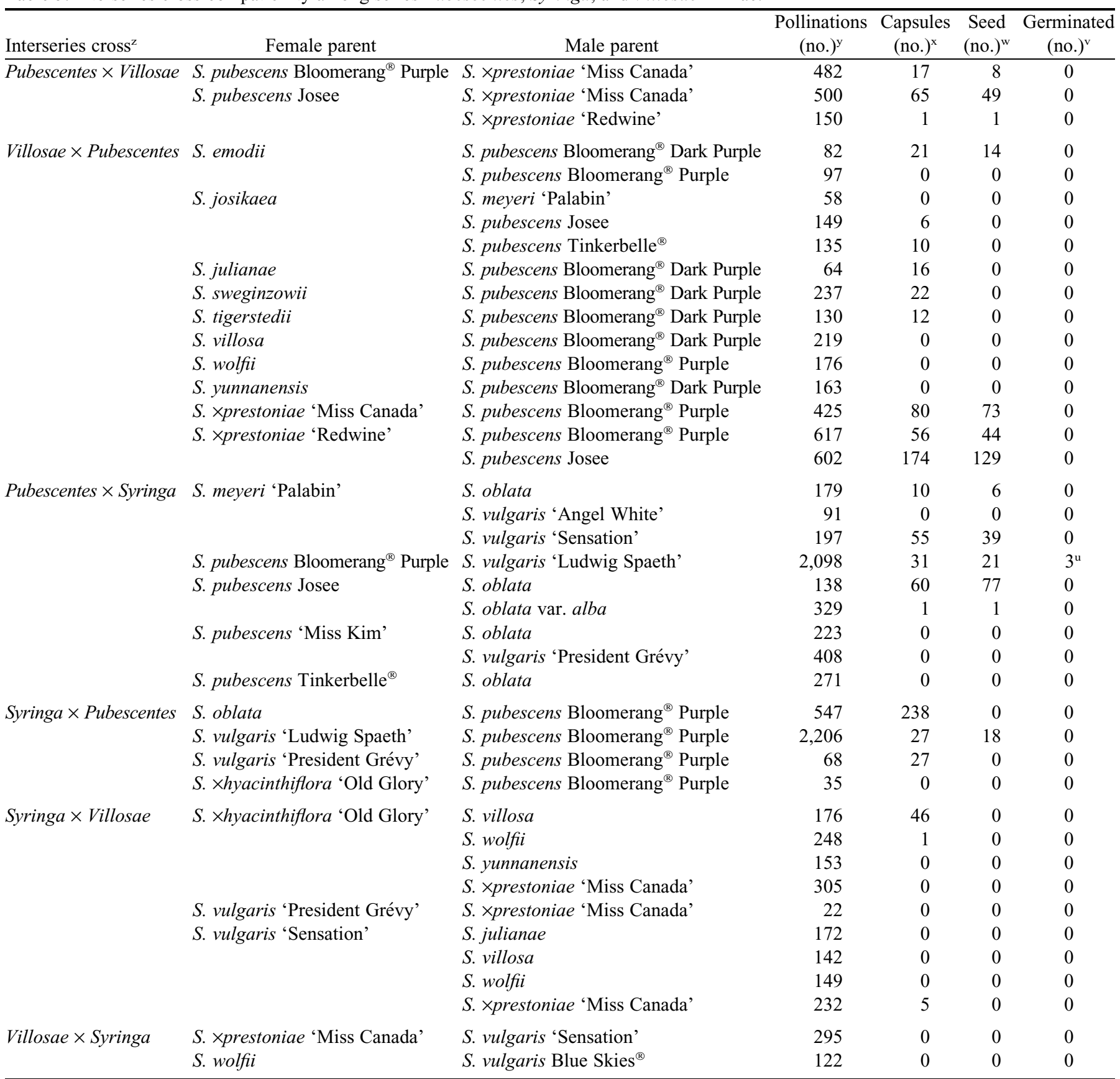

${ }^{\mathrm{Z}}$ Interseries crosses representing six reciprocal combinations of three series of lilac: Pubescentes, Syringa, and Villosae (Li et al., 2012).

${ }^{\mathrm{y}}$ Number of emasculated flowers pollinated.

${ }^{\mathrm{x}}$ Number of capsules formed from controlled crosses.

${ }^{\mathrm{w}}$ Number of seed produced from controlled crosses.

${ }^{v}$ Number of seed germinated.

'Attempted vitro germination of seed on Monnier's medium according to Zhou et al. (2003); seedlings did not survive germination.

used successfully as both a seed and pollen parent in intraspecific crosses. As a seed parent, $S$. vulgaris Tiny Dancer was compatible with $S$. vulgaris 'Sensation' at 0.14 seedlings per pollinated flower, whereas the reciprocal cross yielded 0.21 seedlings per pollinated flower. As a pollen parent, $S$. vulgaris Tiny Dancer was compatible with $S$. vulgaris Blue Skies ${ }^{\circledR}$ at 0.61 seedlings per pollinated flower and $S$. vulgaris 'Lavender Lady' at 0.27 seedlings per pollinated flower (Table 3). Syringa vulgaris 'President Grévy' had few successful crosses. As a seed parent,
807 intraspecific pollinations were performed with four taxa, and only one seedling was produced from a cross with $S$. vulgaris 'Sensation' (Table 3). As a pollen parent, 740 pollinations were performed with $S$. vulgaris 'President Grévy' on three taxa. Only $S$. vulgaris Blue Skies ${ }^{\circledR}$ proved an effective seed parent, with 12 seedlings produced at 0.05 seedlings per pollination (Table 3 ).

INTERSPECIFIC HYBRIDIZATION. Within series Pubescentes, interspecific crosses were performed between cultivars of $S$. pubescens and S. meyeri 'Palabin'. A total of 2649 pollinations 
Table 6. Attempted pollinations, recovered seed, and in vitro germination of interseries lilac hybrids in 2013. All seed collected from green capsules and cultured on cultured on Monnier's medium as described by Zhou et al. (2003).

\begin{tabular}{|c|c|c|c|c|}
\hline Female parent & Male parent & Pollinated flowers (no.) & Seed (no.) & Germinated (no.) \\
\hline S. vulgaris 'Ludwig Spaeth' & S. pubescens Bloomerang ${ }^{\circledR}$ Purple & 2,206 & 18 & 0 \\
\hline \multirow[t]{2}{*}{ S. meyeri 'Palabin' } & S. oblata & 179 & 6 & 0 \\
\hline & S. vulgaris 'Sensation' & 197 & 39 & 0 \\
\hline \multirow[t]{2}{*}{ S. pubescens 'Miss Kim' } & S. oblata & 223 & 0 & 0 \\
\hline & S. vulgaris 'President Grévy' & 408 & 0 & 0 \\
\hline
\end{tabular}

${ }^{\mathrm{z}}$ Early abortion of 238 fruit occurred 6 weeks postpollination.

${ }^{\mathrm{y}}$ Radicle, hypocotyl, and cotyledons emerged; seedlings failed to grow postgermination and tissues subsequently converted to callus.

resulted in an average of $96.29 \pm 37.12$ viable seedlings per cross (Table 4). Of the seven crosses, two failed to produce viable seedlings. As a seed parent, S. pubescens 'Miss Kim' yielded 149 nonviable, albino seedlings, whereas reciprocal crosses yielded no seedlings after 522 pollinations (Table 4). The most prolific cross, $S$. meyeri 'Palabin' x $S$. pubescens Bloomerang ${ }^{\circledR}$ Purple, yielded 278 seedlings at 1.16 seedlings per pollinated flower (Table 4).

Within series Syringa, interspecific crosses were performed among taxa of $S$. vulgaris, $S$. Xhyacinthiflora, and S. oblata. A total of 3518 pollinations resulted in an average of $31.71 \pm$ 10.93 viable seedlings per cross (Table 4 ). Of the 24 crosses, 15 resulted in viable seedlings. The most prolific cross was $S$. vulgaris Blue Skies ${ }^{\circledR}$ x S. xhyacinthiflora 'Betsy Ross' producing 1.41 seedlings per pollinated flower (Table 4). Although S. oblata was successful in a number of interspecific crosses, the white-flowered S. oblata var. alba produced large seedling populations only in crosses with $S$. vulgaris Tiny Dancer. This cross produced 68 viable seedlings at 0.40 seedlings per pollination, whereas the reciprocal cross produced 47 seedlings at 0.23 seedlings per pollination (Table 4).

Not surprisingly, cultivars of $S$. xhyacinthiflora, crossed successfully with cultivars of $S$. vulgaris and wild-type $S$. oblata. Crosses with $S$. Xhyacinthiflora 'Old Glory' were of interest for future breeding because of the lack of flower and form diversity in purple-leaved cultivars. Syringa Xhyacinthiflora 'Old Glory' proved a successful seed parent in crosses with white-flowered S. vulgaris 'Angel White', yielding 37 seedlings at 0.19 seedlings per pollinated flower (Table 4). Despite 176 pollinations and 76 recovered seed, $S$. xhyacinthiflora 'Old Glory' produced no viable seedlings with the double-flowered S. vulgaris 'President Grévy'. When crossed with the dwarf $S$. vulgaris Tiny Dancer, $S$. Xhyacinthiflora 'Old Glory' proved an efficient seed parent producing 37 seedlings at 0.30 seedlings per pollination. The reciprocal cross was even more efficient, yielding 160 seedlings at 0.96 seedlings per pollination (Table 4 ).

Within series Villosae, only three of 14 crosses produced seedlings. A total of 2997 pollinations yielded an average of $9.29 \pm 7.19$ seedlings per cross combination (Table 4). The most prolific cross was $S$. julianae x $S$. xprestoniae 'Miss Canada' which produced 100 viable seedlings at 0.48 seedlings per pollinated flower (Table 4). In addition, S. julianae had some of the largest flowers in series Villosae with a fragrance reminiscent of $S$. vulgaris. The only other seed parent to produce viable seedlings in interspecific crosses in series
Villosae was $S$. wolfii. The cross between $S$. wolfii and the yellow-leaved $S$. emodii (Fig. 1A) produced 24 seedlings at 0.11 seedlings per pollinated flower (Table 4). Only six seedlings resulted from crosses between $S$. wolfii and $S$. villosa yielding 0.03 seedlings per pollinated flower (Table 4).

INTERSERIES HYBRIDIZATION. Interseries crosses proved the most challenging because of differences in bloom time. It took 3 years to complete a range of interseries crosses. A typical lilac will bloom for 6 weeks in an average season with reliable patterns of bloom across series and species (Fiala, 1988). Our observations agreed with Fiala (1988) with members of series Syringa blooming first in spring, followed by series Pubescentes in late spring to early summer and series Villosae in early to midsummer. During the first year, pollen was collected from early-blooming plants and the sequence of blooming was noted across all taxa. Bloom data were used to design reciprocal interseries crosses over the following 2 years where temperature was altered to hasten or slow bloom. Earlier bloom times were induced in late-blooming taxa using a heated glasshouse. Delayed bloom times were induced in early-blooming taxa using a walk-in cooler.

For series Pubescentes, Syringa, and Villosae, there were six possible combinations of interseries crosses (Table 5). A total of 41 crosses were performed across these six combinations representing 13,092 pollinations (Table 5). No viable seedlings were recovered although some crosses produced capsules and seed (Table 5). Across all the interseries combinations, 975 capsules were recovered which produced 480 seed. Seedproducing crosses could provide a foundation for future studies on embryo abortion and embryo rescue.

Interseries crosses between Pubescentes and Villosae included seven crosses that produced capsules and seed. These crosses included $S$. emodii and cultivars of $S$. pubescens and $S$. xprestoniae (Table 5). Capsules and seed were produced when taxa in Pubescentes and Villosae were used as seed parents. The most prolific cross was $S$. × prestoniae 'Redwine' $\times S$. pubescens Josee which produced 129 seed from 174 capsules after 602 pollinations (Table 5 ).

Interseries crosses between Pubescentes and Syringa included five crosses that produced capsules and seed. Only one cross produced seed with series Syringa as a seed parent, $S$. vulgaris 'Ludwig Spaeth' x S. pubescens Bloomerang ${ }^{\circledR}$. This cross resulted in 27 capsules and 18 seed after 2206 pollinations (Table 5). Four crosses produced seed using series Pubescentes as a seed parent. The cross S. oblata $\mathrm{x}$ S. pubescens Bloomerang ${ }^{\circledR}$ Purple produced the most capsules of any interseries cross at 
238 capsules from 547 pollinations. However, these capsules aborted 6 weeks after pollination, unlike most interseries capsules which persisted for the 20- to 30-week development period. The most prolific cross between series Pubescentes and Syringa was $S$. pubescens Josee x $S$. oblata, yielding 77 seed from 138 pollinations at 0.56 seed per pollination (Table 5).

No interseries cross between series Syringa and Villosae produced seed-filled capsules. Of the 2016 pollinations, capsules were produced from three crosses: $S$. $\times$ hyacinthiflora 'Old Glory' x $S$. villosa, $S$. ×hyacinthiflora 'Old Glory' x $S$. wolfi, and $S$. vulgaris 'Sensation' $\mathrm{x} S$. × prestoniae 'Miss Canada' (Table 5). The most prolific cross was $S$. ×hyacinthiflora 'Old Glory' x S. villosa which yielded 46 capsules from 176 pollinations (Table 5).

In VITRO GERMinAtion. A preliminary trial extracting openpollinated lilac seed and embryos from green capsules revealed the difficulty of embryo extraction at this young stage. Oxidation of the young seed progressed rapidly during excision and phenolics proved damaging when immature seed were cultured in vitro. Excising seed while submerged in an antioxidant solution reduced oxidation and allowed extraction of undamaged green seed. Immature seed obtained from interseries crosses in 2013 had low germination in vitro on Monnier's medium (Table 6). Most seed failed to germinate and eventually became necrotic. Of the 161 seed cultured in vitro, only three germinated, all from the cross $S$. pubescens 'Penda' Bloomerang ${ }^{\circledR}$ Purple x S. vulgaris 'Ludwig Spaeth' (Table 6). Seedlings failed to grow post germination and tissues, including cotyledons, subsequently converted to callus. This result may be due to lack of proper transfer media postgermination or lack of proper combination of genotype and in vitro germination medium. Surprisingly, Zhou et al. (2003) did not report the genotype used in their protocol. Further research will be necessary to design protocols for in vitro seed germination and embryo rescue in lilac. Callus obtained from cotyledons could provide source material for somatic embryogenesis in future studies, as demonstrated by Liu et al. (2013).

Though interseries crosses and in vitro germination failed to achieve hybrids, the quantity of seed produced combined with several seed that germinated in vitro provides evidence that future work on wide hybridization in lilacs may prove fruitful. Anatomical studies have shown that low-germination lilac seed contain embryos that progress to walking stick stage before abortion (Chen et al., 2012). This study lists individual cross combinations between series Pubescentes and Villosae, as well as Pubescentes and Syringa, which produced large numbers of seed (Table 5). In addition, current research at North Dakota State University also observed fruit development in interseries crosses between series Villosae and the tree lilacs in Ligustrina that persisted well into the summer before fruit abortion (N.G. Maren, personal communication).

This study represents a comprehensive investigation of lilac cross-compatibility. Intraspecific and interspecific crosses produced hybrid progeny from a diverse set of crosses. The resulting seedlings will be used to study phenotypic segregation of flower traits such as color, double flowers, picotee petals, and remontancy. Seedlings from crosses with $S$. vulgaris Tiny Dancer will be used to study segregation of the dwarf phenotype. Seedlings from crosses Syringa $\times$ hyacinthiflora 'Old Glory' and $S$. emodii will be used to study segregation of the purple- and yellow-leaved phenotypes, respectively. Selections among hybrid seedlings may identify novel combinations of traits such as purple-leaved dwarfs, double-flowered dwarfs, or double-picotee flowers.

Cross-incompatibility may be due to differences in genome size and ploidy level. Future evaluation of genome size and ploidy among taxa may provide insight into cross-compatibility in the current study. Cytological studies describe lilacs to be primarily diploids (Darlington and Wylie, 1956) with holoploid genome sizes near 2.5 pg (Olszewska and Osiecka, 1984; Siljak-Yakovlev et al., 2010). Cross-incompatibility can also be a function of pollination biology. Self-incompatibility systems have been discovered in related genera (Phillyrea, Fraxinus, and Olea) and sporophytic cross-incompatibility systems with $S$-allele dominance relationships have been discovered in cultivars of Olea (Breton et al., 2014; Collani et al., 2012; Koubouris et al., 2014; Saumitou-Laprade et al., 2017; Vernet et al., 2016). Future studies investigating rates of gametophytic/sporophytic incompatibility and unreduced gametes may provide insights into cross-compatibility. Environmental conditions have also been shown to affect seed development in lilacs (Junttila, 1973), and the current study may provide crosses useful for determining optimum greenhouse temperatures for pollination.

While many intraspecific and interspecific crosses were successful, no interseries crosses yielded viable seedlings. Some interseries crosses did, however, produce capsules and seed. A preliminary in vitro germination trial yielded low germination percentage and callus production. These results provide evidence that interseries hybrids among series Syringa, Pubescentes, and Villosae may be possible. Interseries seed development in hybrids with Ligustrina have also shown promise. In future research, seed-producing interseries crosses could be repeated and anatomical studies on embryo development, similar to Chen et al. (2012), may yield important information for targeting future embryo rescue efforts. Openpollinated seed could be used to identify suitable culture media. Tissue culture and embryo rescue protocols are highly genotypespecific; therefore, cross-specific embryo rescue and embryogenic callus media could be fine-tuned for interseries hybrids that produce viable embryos early in seed development. Recovery of interseries hybrids in lilac will likely prove difficult. However, the current study in combination with other breeding and tissue culture studies provides a foundation for development of novel hybrid lilacs. For a group of ornamental shrubs and trees that have been bred for nearly 500 years, there are still new horizons for breeders to pursue in modern lilac breeding.

\section{Literature Cited}

Breton, C.M., D. Farinelli, S. Shafiq, J.S. Heslop-Harrison, M. Sedgley, and A.J. Bervillé. 2014. The self-incompatibility mating system of the olive (Olea europaea L.) functions with dominance between $S$-alleles. Tree Genet. Genomes 10:1055-1067.

Chen, J.-Y., Z.-S. Zhang, and D.-Y. Hong. 2009. A taxonomic revision of the Syringa pubescens complex (Oleaceae). Ann. Mo. Bot. Gard. 96:237-250.

Chen, Y., J.-Y. Chen, Y. Liu, and S.-W. Zhao. 2012. Anatomical study on seed abortion of Syringa villosa under cultivated conditions. J. Beijing For. Univ. 34:107-114.

Collani, S., G. Galla, A. Ramina, G. Barcaccia, F. Alagna, E.M. Càceres, L. Baldoni, R. Muleo, and G. Perrotta. 2012. Self-incompatibility in olive: A new hypothesis on the $S$-locus genes controlling pollenpistil interaction. Acta Hort. 967:133-140.

Dadpour, M.R., S. Naghiloo, S.H. Peighambardoust, S. Panahirad, M. Aliakbari, and A. Movafeghi. 2011. Comparison of floral ontogeny in 
wild-type and double-flowered phenotypes of Syringa vulgaris L. (Oleaceae). Sci. Hort. 127:535-541.

Darlington, C.D. and A.P. Wylie. 1956. Chromosome atlas of flowering plants. Macmillan, New York, NY.

Fiala, J.L. 1988. Lilacs: The genus Syringa. Timber Press, Portland, OR. Fiala, J.L. and F. Vrugtman. 2008. Lilac: A gardener's encyclopedia. 2nd ed. Timber Press, Portland, OR.

Junttila, O. 1973. Seeds and embryo germination in Syringa vulgaris and $S$. reflexa as affected by temperature during seed development. Physiol. Plant. 29:264-268.

Kim, K.-J. and R.K. Jansen. 1998. A chloroplast DNA phylogeny of lilacs (Syringa, Oleaceae): Plastome groups show a strong correlation with crossing groups. Amer. J. Bot. 85:1338-1351.

Kochieva, E.Z., N.N. Ryzhova, O.I. Molkanova, A.M. Kudryavtsev, V.P. Upelniek, and I.B. Okuneva. 2004. The genus Syringa: Molecular markers of species and cultivars. Russ. J. Genet. 40:30-32.

Koubouris, G.C., C.M. Breton, I.T. Metzidakis, and M.D. Vasilakakis. 2014. Self-incompatibility and pollination relationships for four Greek olive cultivars. Sci. Hort. 176:91-96.

Lemoine, V. 1878. Syringa hyacinthiflora plena. Catalogue 78, p. 6. Nancy.

Li, J., B. Goldman-Huertas, J. DeYoug, and J. Alexander, III. 2012. Phylogenetics and diversification of Syringa inferred from nuclear and plastid DNA sequences. Castanea 77:82-88.

Liu, C.-P., L. Yang, H.-L. Shen, and J.-M. Cong. 2013. Somatic embryogenesis and plant regeneration from immature embryo cotyledons of Syringa reticulata Blume var. mandshurica Hara. Propag. Ornam. Plants 13:65-72.

Monnier, M. 1990. Culture of zygotic embryos of higher plants. Methods Mol. Biol. 6:129-139.
Olszewska, M.J. and R. Osiecka. 1984. Relationship between 2C DNA content, systematic position and level of DNA endoreplication during differentiation of root parenchyma in dicot shrubs and trees. Comparison with herbaceous species. Biochem. Physiol. Pflanz. 179:641-657.

Pringle, J.S. 1981. A review of attempted and reported interseries and intergeneric hybridization in Syringa (Oleaceae). Baileya 20:49-91.

Rehder, A. 1945. Notes on some cultivated trees and shrubs. J. Arnold Arbor. 26:67-78.

Saumitou-Laprade, P., P. Vernet, X. Vekemans, S. Billiard, S. Gallina, L. Essalouh, A. Mhaï, A. Moukhli, A. El Bakkali, G. Barcaccia, F. Alagna, R. Mariotti, N.G.M. Cultrera, S. Pandolfi, M. Rossi, B. Khadari, and L. Baldoni. 2017. Elucidation of the genetic architecture of self-incompatibility in olive: Evolutionary consequences and perspectives for orchard management. Evol. Appl. (In press).

Sax, K. 1930. Chromosome number and behavior in the genus Syringa. J. Arnold Arbor. 11:7-14.

Siljak-Yakovlev, S., F. Pustahija, E.M. Šolić, F. Bogunić, E. Muratović, N. Bašić, O. Catrice, and S.C. Brown. 2010. Towards a genome size and chromosome number database of Balkan flora: C-Values in 343 taxa with novel values for 242. Adv. Sci. Lett. 3:190-213.

U.S. Department of Agriculture. 2016. Census of horticultural specialties for 2014. 15 July 2016. < https://www.agcensus.usda.gov/Publications/ 2012/Online_Resources/Census_of_Horticulture_Specialties/>.

Vernet, P., P. Lepercq, S. Billiard, A. Bourceaux, J. Lepart, B. Dommée, and P. Saumitou-Laprade. 2016. Evidence for the longterm maintenance of a rare self-incompatibility system in Oleaceae. New Phytol. 210:1408-1417.

Zhou, L., L.-M. Dai, and B.-L. Su. 2003. Embryo culture and rapid propagation of Syringa. J. For. Res. 14:213-216. 